\title{
COMMUNICATION MANAGEMENT IN PROMOTING KNOWLEDGE AND CREATIVITY IN FOSTERING INNOVATIONS IN THE CREATIVE ORGANIZATIONS
}

\author{
Zenona Ona ATKOČIŪNIENË ${ }^{1 *}$, Daiva SIUDIKIENĖ ${ }^{2}$ \\ ${ }^{1}$ Department of Creative Communication, Faculty of Creative Industries, \\ Vilnius Gediminas Technical University, Traku str. 1, 01132 Vilnius, Lithuania \\ ${ }^{2}$ Department of Organizational Information and Communication Research, Faculty of Communication, \\ Vilnius University, Sauletekio av. 9, I House, 10222 Vilnius, Lithuania
}

Received 2 September 2021; accepted 16 November 2021

\begin{abstract}
The topic of innovation is extremely important because it relates to the ability of organizations, urban regions and even states to remain competitive in today's rapidly changing world. The problem for modern organizations is how to increase the scale and efficiency of innovation in modern organizations. One of the most striking modern trends that helps to generate innovation is the involvement of the organization's stakeholders in the processes of value co-creation, encouraging their processes of collective cooperation, knowledge sharing and creative expression. Changing value creation processes are becoming a critical factor in creating innovation. Value creation has always been an essential foundation of any organization's activities, but the targeted involvement of stakeholders in value creation is a relatively new phenomenon. The article presents a study, the aim of which is to investigate how and in what forms creative organizations - publishing houses - use the adaptability of their managed communication channels to encourage stakeholder involvement in value co-creation processes in innovation. Stakeholder involvement in the development of new ideas and projects, networking, collaboration, knowledge sharing, various non-formal learning opportunities, creation of discussion and feedback platforms as important drivers of stakeholder engagement are particularly important in fostering value-added processes in innovation.
\end{abstract}

Keywords: communication, creative organizations, creativity, innovation, innovative knowledge, stakeholder involvement, value creation.

\section{Introduction}

In the context of global change, it is acknowledged that the ability of organizations, regions or even states to remain competitive is closely related to their readiness to develop innovations and to create conditions favorable for their development (Vlok, 2012). The topic of innovation is extremely important as it pertains to the possibilities to survive in the today's rapidly changing world. Investments being the basis for long-term economic growth determine that

${ }^{\star}$ Corresponding author. E-mail: zenona-ona.atkociuniene@vilniustech.lt

Copyright (C) 2021 The Author(s). Published by Vilnius Gediminas Technical University

This is an Open Access article distributed under the terms of the Creative Commons Attribution License (http://creativecommons. org/licenses/by/4.0/), which permits unrestricted use, distribution, and reproduction in any medium, provided the original author and source are credited. 
countries and organizations invest in innovations in various sectors and activity areas, seeking to increase operational efficiency, develop and introduce new equipment, technologies, new management and marketing practices. However, despite significant investments in innovation, it is acknowledged that the return on investment is relatively low. It is noted that a large share of innovation-oriented organizations operate inefficiently (Schork et al., 2016; Zerfass \& Huck, 2007; Mast et al., 2005), and that processes related to innovation activities are poorly studied and lack a deeper analysis (Granados et al., 2017).

Socio-economic changes, which intensified in the world in the middle and at the end of the 20th century, have determined the significance of the increased link between culture and economy. Creative industries are emerging as the largest source of innovation in the modern economy, and their developed ideas can be applied to other sectors as well (Trüby et al., 2008). Creative industries encompass technologies, media, and business, while creativity is closely linked to manifestation of knowledge and skills in the enterprising environment saturated with technologies and the media (Kačerauskas, 2017). Creative industries are seen as a sector that has great economic potential. It has been observed that by developing inter-sectorial innovations the creative economy influences social development (Makselis, 2014; Lazzeretti, 2013). It can be noticed that these processes are multifaceted, complex and distinguish themselves by peculiar specificity. The important aspects emphasized by various authors analyzing the processes of the innovation activity are the organization's strategic approach to the innovation activity (Zerfass, 2005), the need for effective knowledge management (Ode \& Ayavoo, 2020; Ryan \& Daly, 2019), the necessity of innovative leadership (Atkočiūnienè et al., 2019; Schork et al., 2016; Horth \& Buchner, 2014; Baumgartner, 2014), the importance of organizational creativity (Brem et al., 2019; Beckett \& Hyland, 2009; Cronquist et al., 2006), the significance of an innovative organizational culture (Winkler \& Zerfass, 2016), a significant role of communication in the processes of innovation creation and implementation (Cina \& Cummings, 2018; Linke \& Zerfass, 2011; Beckett \& Hyland, 2009; Zerfass \& Huck, 2007). It should be noted that all these aspects are significant, but the question arises as to how all these important components of innovation activities should be enabled and how their interaction should be promoted to achieve effective continuous innovation activities of organizations. One of the most relevant issues modern organizations encounter is how to increase the scale and efficiency of innovation in modern organizations. One of the most striking modern trends, helping to generate innovations, is the involvement of organizational stakeholders in value co-creation processes by encouraging the processes of their collective collaboration, knowledge-sharing and creative manifestation (Fan \& Luo, 2020; Kim \& Choi, 2019; Helkkula et al., 2012). Creative industries are treated as a sector that is particularly innovation-active; therefore, in the context of today's relevant issues, a particularly significant research problem arises - enabling the interaction between communication, knowledge and creativity while developing innovations in creative organizations and involving all stakeholder groups in value co-creation processes.

The aim of the research is to identify how communication management solutions determine creativity of the organization's stakeholder groups in creating continuous knowledge-based innovations in creative organizations. To achieve the aim, the following research objectives were formulated: to reveal the importance of communication management as 
the organization's essential activity in creating innovations in the context of change in the dynamic environment; to analyze the manifestations of creativity and knowledge management as potential factors promoting innovation; to reveal the links between communication, knowledge and creativity in the innovation development process in creative organizations; to investigate the applicability possibilities of corporate websites of publishing houses and the social network Facebook, attempting to engage stakeholder groups in innovation activities. The paper was written employing scientific research methods: the analysis of scientific literature, synthesis, secondary data analysis and qualitative semi-structured interviews with the representatives of organizations of creative industries, interpretation and summary of results.

\section{Theoretical foundations}

\subsection{Transformations of modern organizations and promotion of innovation in creative organizations}

At the change of epochs and Fourth Industrial Revolution, it is important for organizations to envisage new directions to achieve progress and competitive advantage in the conditions of growing global competition. Over the last 20 years, the organizational environment has changed dramatically, but the governance of organizations is still based on the approaches to the industrial organization (Sydänmaanlakka, 2008). The industrial era distinguished itself by mass production, unification and foresight of processes, while the post-industrial period is characterized by flexibility, choice and personal responsibility. Hierarchical structures and vertical relationships are being replaced by the networks of power and influence and horizontal relationships (Gill et al., 1999). It is noted that modern organizations have to change in order to survive in the market (Cronquist et al., 2006). In the era of the digital economy, organizations have to change the ways of organizing their work, look for new niches to gain a competitive advantage of the organization in the global space by developing new branches of industry, markets, products and services (Zerfass, 2005). It is stated that the need for innovation becomes particularly pronounced during the periods of economic downturn, as the ability to introduce novelties is a key driver promoting economic growth and social welfare (Huck 2006). Innovation is a source of competitive advantage for any organization (Ackermann, 2013; Vlok, 2012; Strazdas, 2011; Beckett \& Hyland, 2009; Huck, 2006; Cronquist et al., 2006), the basis for long-term economic growth (Vlok, 2012; Huck, 2006), and the engine of profitability and development (Ackermann, 2013; Strazdas, 2011; Zerfass, 2005).

In the context of global change, innovation is seen as a part of strategic management (Beckett \& Hyland, 2009; Zerfass, 2005), while investment in innovation in various activity areas is growing to increase operational efficiency, develop and introduce new equipment, technologies, new management and marketing practices. Innovation is a functional, fundamentally advanced novelty oriented to replacing the old with the new. The Lithuanian Innovation Development Programme 2014-2020 (Government of the Republic of Lithuania, 2013) defines innovation as the introduction of new or substantially improved products (goods or services) or processes, new marketing or organizational methods in business practice, organization or by developing external relationships. Innovation can be considered an idea, activity or some material object that is new to people, their group or the organization 
implementing or using it (Strazdas et al., 2003). Innovation does not necessarily have to be grounded on technologies, it can also emerge by reorganizing services, marketing and sales methods, financing models and the organizational culture itself, which enables to increase customer benefits and market share, optimize operational and management processes, and increase competitiveness (Zerfass, 2005). Particular emphasis is placed on the aspect of rationality, applicability and utility as essential in innovation activities (Zerfass, 2005; Hargie \& Tourish, 1996). In the field of innovation, creativity, science, research activities and entrepreneurship intersect, transforming scientific knowledge into a physical reality that is changing the society. It is appropriate to treat innovation activities as productive human activities oriented to the transition of some system from a lower level to a higher one. The aim of this transition is to meet the changing needs of the society.

A number of authors emphasize that innovation emerges in multi-channel dynamic ecosystems of innovation, composed of researchers, funders, entrepreneurs, legislators, experts, and employees, in which dynamic processes of creating novelties and experimentation take place (Ackermann, 2013; Luoma-aho \& Halonen, 2010; Jansen et al., 2006); therefore, effective interaction between actors is a condition for productive innovation activity. The innovation activity is a complex process taking place in certain stages. It is influenced by both the internal and external environment of the organization (Zerfass, 2005) and involves many actors (Luoma-aho \& Halonen, 2010). Innovation requires the use of external and internal resources and respective knowledge, technologies, and effective decisions for a smooth transition from one stage to another (Beckett \& Hyland, 2009). Innovation can occur only in a certain environment; i.e., only in those organizations in which an innovation-friendly organizational culture is created and fostered (Winkler \& Zerfass, 2016; Luoma-aho \& Halonen, 2010; Kenney, 2000). According to researchers, effective creation of innovation requires continuous development, organization and management of innovation activities by applying a respective organizational structure, systemic approach, and mechanisms supporting this activity (Chutivongse \& Gerdsri, 2020; Drucker, 2006). Thus, the innovative organization is an organization that generates and introduces novelties in its activities and carries out continuous innovation activities. Summarizing research on innovative organizations, Chutivongse and Gerdsri (2020) distinguish 10 dimensions of the innovative organization: strategy oriented to promotion of innovation, leadership, culture, organizational structure, processes, people, relationships/networks, infrastructure of technologies, measurement of innovative performance indicators, and learning. Innovation activity can be described as a complex process encompassing the creation, dissemination and use of the novelty.

Changing value creation processes become a critical factor in the development of innovation (Kim \& Choi, 2019; Helkkula et al., 2012). Value creation has always been an essential foundation of any organization's activities, but targeted involvement of stakeholders in value co-creation is a relatively new phenomenon. Co-creation takes place when different stakeholder groups work together to create a mutually beneficial outcome. Participation of many stakeholders in value creation enables to understand the demand and helps to implement the organization's strategy (Pfitzer et al., 2013), to realize market changes, and to share knowledge and abilities (Fan \& Luo, 2020). Looking at value co-creation from the perspective of the innovation paradigm, particular emphasis is placed on stakeholder collaboration and 
interaction, highlighting the significance of customer input to the development of innovation (Fan \& Luo, 2020; Gustafsson et al., 2012; Atanassova \& Clark, 2015; Martini et al., 2014). According to Ramírez and García-Peñalvo (2018), shared value creation is an open innovation encompassing knowledge, information and related skills in various institutional settings and promoting involvement of many actors, which is a weighty basis for enterprises to acquire sustainable competitive advantage. The digital environment provides opportunities for more active interaction with customers and other stakeholders and for using their insights to develop innovation (Atanassova \& Clark, 2015; Kim \& Choi, 2019) and enables the development of new digital business models (de Oliveira \& Nogueira Cortimiglia, 2017). Innovation activities in value co-creation processes become more efficient as organizations involve more actors from different settings in their activities (López-Rubio et al., 2020; Hein et al., 2019), use contacts and strategic partnerships (Hein et al., 2019), this way being able to more quickly identify the needs and problems of stakeholders, hear and consider various proposals (Ranjan \& Read, 2016), understand value dimensions from the perspective of other groups (Boyd \& Koles, 2019), enable manifestation of stakeholders' creativity and knowledge, promote knowledge-sharing (Jun \& Kim, 2021), use not only internal but also external resources (Hein et al., 2019), accelerate organizational learning (Mastio et al., 2020), develop new ideas more consistently and ensure their implementation and dissemination (Gustafsson et al., 2012). It is evident that the need for promoting creative collaboration of various stakeholders, generation of new ideas, sharing knowledge and experience acquire increasing importance in innovation activities and value co-creation processes; therefore, communication management solutions must be strategized accordingly.

Seeking innovative solutions in the creative industries sector of the 21 st century, particularly much attention is paid to the development of collective creativity and collaboration. It is observed that theories of creative industries and creative economy no longer give prominence to a solitary individual's talent - they approach the conception of collective or social systems: networks supporting creativity are expanding both horizontally to cultural and aesthetic communities and vertically to managerial implementation and dissemination systems (Černevičiūtė et al., 2015). Creative industries in Lithuania include: crafts, architecture, design, cinema and video art, publishing, visual, applied arts, music, software and computer services, development and broadcasting of radio and television programs, advertising, performing arts and other fields in which the aspects of cultural and economic activity connect (Martinaitytė \& Kregždaitè, 2013, 2015). It is acknowledged that the share of the creative sector, growing in the modern economic system, generating income and creating jobs, equalizes the overall economic balance by compensating for the declining contribution from traditional branches of industry. It is also important to accentuate that creative industry organizations are becoming a particularly favorable medium for innovation, as they can offer sufficient space, openness and the necessary intellectual resources for the development of new ideas, the specificity of which enable to apply them directly or indirectly to other economic sectors that are completely unrelated to creative industries by means of creative products and ideas (Martinaitytė \& Kregždaitè, 2013, 2015; Lazzeretti, 2013). It was namely creative organizations that began to apply models of generating new ideas, promoting various stakeholder groups' collaboration, idea sharing, collective collaboration in the risk-tolerant 
environment that encouraged applicability of various creative methods, learning from mistakes, and the use of new and unusual decisions for solving arising problems. From the beginning of consolidation of creative industries in the economic field at the end of the 20th century till today, creating the environment favorable to creative ideas and universal performance, which are afterwards applied in a broad inter-sectoral context, creative industries became a driving force for innovations and economic development.

\subsection{Dimensions of knowledge management and creativity in innovation activities}

The condition of the process of creating innovations is the creative use of knowledge and research (Sapiegienè et al., 2009). Raudeliūnienè (2012) notes that an important competitive factor for the organization with quite limited resources, which seeks to make its activities more efficient in a dynamic environment, is knowledge and its management processes - purposeful generation, dissemination and application of knowledge. It is crucial for organizations that the "lessons learned" and knowledge created by employees remain in the organization so that it can be taken over by other members of the organization. Knowledge management is related to innovations, interrelationships, ideas, competencies, and structures. This management supports individual or group learning, encourages dissemination of experiences, distinguishes between unsuccessful and best practices, and helps to select optimal solutions. Effective knowledge management in the organization is perceived as an essential engine of innovation (Ode \& Ayavoo, 2020; Strazdas, 2011). It is noted that it is namely the applicability of existing knowledge in a new way that has enabled the development of many innovations (Carlson \& Wilmot, 2006). In innovation-oriented organizations, the ability to evaluate and manage knowledge so that it can be used as a basis in decision-making becomes an effective tool for increasing the efficiency of the organizations' activity (Atkočiūnienè et al., 2019).

Maceika and Jančiauskas (2012) note that it is not knowledge in general that is important for business, but rather innovative knowledge, the application of which pertains to new products and services and resulting new markets encouraging the development of the very customers' needs and application of increasingly higher technologies in solving problems of professional activities, cultural development and the like. Thus, while improving the environment of knowledge, we must distinguish knowledge involved in new creative processes resulting in the development of new activity forms, methods, technologies, and therefore, new products and services. Namely the knowledge that usefully participates in creative processes; i.e., developing new products and services, and in production, is innovative. The conception of novelty is identified with knowledge-based business, when the most important condition for continuous improvement is collaboration by integrating specialists' individual knowledge, applying it, and developing innovative products and services. Practical applicability problems distinguish themselves by the fact that it is not always possible to acquire practically applicable knowledge or its products in the knowledge market - usually this is offered at the level of ideas or it is difficult to evaluate how they will correspond to the organization's goals and the level of payback of the acquired knowledge (Raudeliūnienè \& Račinskaja, 2014). Collaboration, sharing and development of knowledge in both internal and external environments should constantly take place in the modern organization aiming at the development of open 
and radical innovations. Open formal and informal communication encourages employees to disseminate existing knowledge and generate ideas that can later be improved and used. Organizations should be creating networks and communities in which employees could develop topics of interest to them, learn and improve (Girnienè, 2014). Urgal et al. (2013) note that the interrelationships between knowledge and innovation are based on the fact that knowledge is necessary both for the development of innovation and for its introduction and use. Therefore, in order to develop innovation, it is crucial to evaluate the organization's abilities to acquire new knowledge from different sources and to share the existing knowledge using various contacts. Sharing and transfer of knowledge are basically the provision of knowledge to other members of the organization, but this is effective when all members and departments of the organization are involved in this process. Knowledge sharing in organizations takes place using information technologies and organizations share knowledge by means of increasingly modern forms: cloud computing; learning systems; resource exchange systems; platforms for messaging and video sharing; social networks; audio- and/or video-conferencing; blogs; chat technologies, etc. Knowledge sharing grounded on modern technologies becomes an integral part of the innovative organization, giving it a competitive advantage (Ulbinaite \& Gribovskis, 2020).

The ability of organizations to interact with various partners and to acquire knowledge from external sources provide an opportunity to increase their ability to apply innovations. Communication with other organizations enables to choose more appropriate working methods, develop various technological and innovative abilities and skills, which creates preconditions for emergence of uniqueness of organizations. Proper application of newly acquired knowledge allows organizations to develop unique competencies, select, introduce and improve technologies in their activities (Urgal et al., 2013). The success of innovation development depends on the selection of appropriate sources of knowledge, the way of knowledge acquisition, and the organization's receptivity to knowledge (the ability to coordinate and integrate a wide range of internal and external knowledge), the abilities to overcome barriers to innovation (market, financial barriers manifesting themselves by the lack of required financial resources) and to cope with uncertainty of the market. By properly applying the newly acquired knowledge, organizations have opportunities to develop unique competencies, select, introduce and improve technologies in their activities.

However, significant role in the organization is played not only by effective knowledge management but also by creative applicability of knowledge for the development and dissemination of innovation. The concept of creativity, which for a long time was intended solely for describing the product created by artists, has significantly expanded and is associated with the knowledge society and a new approach to innovation, while creativity is becoming a constituent of economic processes (Martinaitytė \& Kregždaitè, 2013). Creativity is perceived not only as an individual but also as a collective, clearly defined and structured process encompassing not only generation of ideas (divergent thinking) but also implementation of ideas (convergent thinking), oriented to practical benefits (Černevičiūtė \& Strazdas, 2014). Creativity can be defined as the creation of something new, new elements or the solution of problems when the direction has already been chosen, but the organization encounters obstacles that need to be overcome. This requires taking up new ways and using new tools. 
Nowadays, in many national economies and innovative environments, creativity became a very important factor for both large organizations and small enterprises. In many businesses seeking to stay innovative and competitive, creativity acquires a strategic role. In the knowledge-based and creative economy, competitiveness is strengthened through innovation of products and services, which places importance not only on knowledge but also on creativity. The question is how to maximize creativity and innovation. It is assumed that product research is objective as products can be counted, which allows the use of scientific methods. However, some problematicity in this approach is encountered, as more emphasis is placed on productivity rather than creativity. It is noted that productivity can be achieved without originality, but it is widely acknowledged that originality is essential for creativity. The product will correspond to the characteristics of the creative product if it meets two essential conditions: it must be original or new and in a sense useful (Černevičiūtė \& Strazdas, 2014). It is essential that the development of innovations is accompanied by application of methods promoting creativity. More than 200 such methods have been developed and still more are being developed. Such abundance of methods for promoting creativity poses a problem which one to choose. There is no unified system enabling the organization to know how to promote creativity and effective knowledge sharing among its employees. Some researchers provide long lists of techniques for promoting creativity, others limit themselves to just a few essential ones: brainstorming, horizontal thinking, mind mapping, checklist, etc. To achieve positive results from promotion of creativity, the organization must create the environment of creativity, providing the employee with the conditions in the organization to develop and exploit creativity. It is maintained that the appropriate medium for creativity is the one which offers enough resources for creation such as time, place, tolerant environment, and sufficient material resources (Strazdas et al., 2010). Analyzing the processes of knowledge management and promotion of creativity, it can be noticed that they are closely related to communication management in the organization.

\subsection{The role of communication in the innovation-oriented organization}

The innovation-friendly culture in organizations requires open and effective communication (Luoma-aho \& Halonen, 2010; Cronquist et al., 2006), and it is the insufficient innovation communication that causes failures in the field of innovation (Huck, 2006; Zerfass, 2005).

The importance of communication in the innovation promotion process is one of the most relevant aspects of scientific research, the importance of which manifests itself not only as the opportunity to achieve greater operational efficiency during innovation development processes but also to create conditions for further dissemination of innovation (Zerfass \& Huck, 2007; Mast et al., 2005). Innovation communication is considered as a part of strategic (Linke \& Zerfass, 2011) and corporate communication (Ackermann, 2013; Huck, 2006), which encompasses all innovation development processes and ensures the introduction and dissemination of innovation (Ackermann, 2013; Luoma-aho \& Halonen, 2010; Mast et al., 2005). Innovation communication can be defined as the symbolic interaction between the organization and its stakeholders related to innovative products, services, technologies and ideas (Ackermann, 2013; Huck, 2006; Mast et al., 2005). It is noted that the ideas for 
innovation must be searched for in both internal and external settings of organizations, as new products and services will help to meet the needs of clients, community members and citizens (Cina \& Cummings, 2018). Communication is an essential component in innovation processes, ensuring smooth management of all innovation activity processes (Luoma-aho \& Halonen, 2010; Beckett \& Hyland, 2009; Zerfass \& Huck, 2007). It is emphasized that the innovative activity requires effective communication with all internal and external stakeholder groups (Cina \& Cummings, 2018; Atanassova \& Clark, 2015; Ackermann, 2013; Linke \& Zerfass, 2011). Communication is a constituent of the innovation development and implementation process, important elements of each stage of which are promotion of generation of ideas, explanation of the need for innovation, provision of opportunities for manifestation of new ideas, development of relationships both within the team and with stakeholder groups, organization of innovation development activities, involvement of people, constant stimulation of their imagination, maintenance of the spirit of innovation, formation of an innovative worldview of employees through the provision of inspiring examples and supporting materials and by raising awareness of processes and technologies (Zerfass \& Huck, 2007). Communication between employees of the organization is also vital in sharing experiences and knowledge related to the tasks performed, while the use of information and communication systems can enhance informal and formal communication and positively influence organizational processes (Cronquist et al., 2006). Communication must be oriented to promoting and fostering of creativity in the organization, as creativity is the ability to generate new ideas or products based on observed models and relationships, and the key drivers in these processes are knowledge of a specific area and motivation.

Albronda et al. (2011) note that innovation is not just about generating new ideas, as the crucial point is implementation of good ideas and solutions, which depends on how the ideas will be accepted. The authors ground on the diffusion of innovation theory, which states that it is very important to reduce uncertainty for potential customers in the diffusion process as any innovation creates uncertainty and it is very unclear whether it will be superior to old methodologies. According to the theory developer Rogers, diffusion is the process during which innovation is communicated to the members of a social system through certain channels of communication over a defined period of time. The novelty of any idea implies a degree of the unknown and uncertainty, while diffusion should be understood as a social change (Rogers, 1983, p. 11). Thus, the process of innovation diffusion is a very important part of innovation implementation and innovation activities, while the outcome depends on the effectiveness of communication. It is observed that innovation is always related to change and in such periods, all groups of people experience uncertainty and anxiety; therefore, reliability, trust and clarity are highly important in such moments. Hence, based on the insights of various researchers, the following communication functions that are significant in innovative activities can be distinguished: creation and maintenance of the innovative culture in the organization (Linke \& Zerfass, 2011; Benner \& Tushman, 2003), strategy dissemination (Cina \& Cummings, 2018), informing (Huck, 2006), motivating (Zerfass \& Huck, 2007), sharing ideas and knowledge (Jones III, 2017), promotion of creativity (Cronquist et al., 2006), reduction of the unknown and uncertainty among various stakeholders (Linke \& Zerfass, 2011), assurance of learning and collaboration as communication in general is a facilitator and 
enabler of all activity processes (Luoma-aho \& Halonen, 2010). Investigating the contribution of internal communication to creation of the innovation culture in the organization, Linke and Zerfass (2011) note that innovation is always related to transformations of the current situation; therefore, the innovation culture can be created in such organizations where internal communication corresponds to each stage of change, maintaining stakeholders' awareness, understanding, acceptance and action. However, it is emphasized that communication must be carried out with all groups of people, which are important for the organization, coordinating all communication activities, considering the implementation of the strategy, increasing its clarity and understanding among target audiences, involving internal and external stakeholder groups in the implementation of the strategy (Cina \& Cummings, 2018; Mast et al., 2005). Particular importance in innovation activities is placed on all stakeholders' interaction, idea-sharing, development of networks and collective creativity. Summarizing functions of communication in innovation activities, mentioned by various authors, Vilma Luoma-aho and Saara Halonen distinguished the following 8 functions: informing internal stakeholders; informing outside stakeholders; communication as a management function; sharing ideas, promotion of informal conversations and social interaction; networking and establishing new contacts; reputation management; creating organizational culture; and maintaining organizational structure (Luoma-aho \& Halonen, 2010, pp. 12-14). It is noticed that organizations have to develop respective platforms for feedback, discussions and consultations, which engage every team member in the organization's activities, as well as an award system encouraging the development of new, original projects (Mumford et al., 2000). The organization must have an effective operating system of interaction and feedback, providing with opportunities to learn from failures and change (Cina \& Cummings, 2018); communication must be frequent, repetitive and enthusiastic (Lewis et al., 2006). There must be prompt and systematic informing of all members of the community without exception about the goals and reasons for improvement of change and processes, about measures, current and future changes, problems, crisis situations and ways of coping with them (Ruževičius, 2007). Communication must be integrated and properly coordinated (Cina \& Cummings, 2018).

The analysis of researchers' attitudes towards the development of the effective communication system in the innovative organization shows that these insights cover the internal and external organizational communication, micro-, meso- and macro-processes. Looking at these processes from the value co-creation perspective, the whole process of development, implementation and dissemination of innovation becomes much smoother and more consistent. This is determined by close and consistent interaction between the organization and stakeholders, which allows to solve encountered problems creatively, generate new ideas and also find ways to implement them by employing all stakeholders' existing knowledge, experience, creativity, networks, etc.

Today, each organization strives to create an effective communication system in its activities, enabling to manage information and communication flows, purposefully use available communication channels and tools, create communication strategies helping to develop a constructive dialogue and collaboration with all stakeholder groups. Organizations must identify their stakeholder groups, methods of their involvement, participation formats, and frequency respectively according to the stakeholder group (Cortado \& Chalmeta, 2016). 
A particularly important role in communication is played by corporate websites: nowadays, they help to develop organizational activities by performing more than just the function of a business card. The company website is a corporate communication tool that presents the organization's activities, products, contact information, service standards, news, events, marketing campaigns (Bernal Jurado et al., 2018; Hwang et al., 2003). Hwang et al. (2003) note that corporate websites perform many functions and enable to reach all stakeholders by coordinating messaging strategies. In addition to numerous functions, a well-designed website is a tool to shape the organization's image and reputation (Gustavsen \& Tilley, 2003; Schumann et al., 1991), presents the organization to internal and external stakeholder groups (van den Bosch et al., 2006), develops corporate social responsibility activities (O'Riordan \& Fairbrass, 2008), helps to develop partnerships to achieve strategic goals and implement fundamental changes (Jun \& Kim, 2021), to increase stakeholder involvement in the organization's activities (Jun \& Kim, 2021; Hoffmann \& Lutz, 2015), to search for employees (Egerová \& Eger, 2017), acts as an e-commerce and service booking platform (Kim et al., 2012), allows to analyze customer behavior, choices and to build their loyalty (Zhang et al., 2014; Kim et al., 2012), etc. It is noted that in digital organizations, corporate websites are becoming an essential tool for implementation of marketing activities, used to find out the expectations and needs of target customers, build credibility and trust, attract and protect customers, present products and services and successfully sell (Obednikovska et al., 2019). Company websites are essential in achieving the strategic goals of the organization, but their usefulness is determined by various dimensions such as attractive design, navigation, convenience, usefulness of content (García García et al., 2017), etc.

Alongside the website, social networks are becoming a particularly important space for interaction and collaboration. Entrenchment of social networks has fundamentally changed communication of organizations as they have significantly increased stakeholders' opportunities to engage in communication and the opportunities for organizations to develop interactive communication with stakeholders. Social networks provide businesses with a new space for developing their activities and open up completely new activity perspectives (Kim et al., 2011; Razmerita \& Kirchner, 2011), facilitate acquisition of resources, dissemination of novelties and development of strategic partnerships (Tsutsumi et al., 2019), ensure the possibility to promptly reach various stakeholder groups (Ayuso et al., 2006), provide opportunities to develop the dialogue with stakeholders and various opportunities for collaboration (Capriotti et al., 2021; Ayuso et al., 2006), accelerate knowledge-sharing processes and promote nonformal learning from each other (Miller, 2012), enable to develop relationship marketing and conduct market research (Kim \& Choi, 2019), allow to understand market changes and carry out marketing activities (Atanassova \& Clark, 2015), to respond to customer inquiries and needs, to collect and analyze user-related data (Tsutsumi et al., 2019; Rocha et al., 2013), help to shape image and reputation, increase organizational awareness and visibility (Capriotti et al., 2021), to perform social responsibility activities (Cortado \& Chalmeta, 2016), etc. Thus, organizations perceive the benefits of social networks and use them as a means to achieve various goals in activities such as strategic management, scientific research and its development, marketing and sales, finance, human resources, security, sponsorship and advertising, brand management, public relations, crisis management, etc., which have a significant impact 
on the activities of organizations (Parveen et al., 2015). It is namely interactivity, dialogue, sharing, feedback and collaboration opportunities that emerge as essential characteristics of social networks.

Along with the growing scale of the digital economy and e-commerce, effective applicability of communication channels managed by each organization is one of the most important factors ensuring the organization's success. A crucial role in promoting value co-creation processes in innovation activity is played by stakeholder involvement in the generation of new ideas and projects, development of contacts and networks, collective collaboration formats, knowledge sharing and various non-formal learning opportunities, development of platforms for discussion and feedback, and the development of the award system as an important factor promoting stakeholder involvement. It is relevant to investigate how and in what forms organizations exploit the adaptability opportunities of their managed communication channels for promotion of stakeholder engagement in value co-creation processes in the innovation activity.

\section{Methodology}

The study was conducted by choosing creative industry organizations. These were publishing houses - a very important sector of cultural and creative industries, which experienced many challenges and deep transformations in the 21st century. Book publishing is an organizational activity with a centuries-old but dynamic structure, production fields, resources, communication chain, legal regulations, while the activity itself consists of ordering, production, distribution and sales. Traditionally, the main actors in the field of literature production have been authors, agents, publishers, distributors, and various intermediaries. Along with the expansion of digitization, their numbers are changing, some intermediate chains are eliminated, authors can publish their works, engage in their marketing and distribution without the publisher's help, while relationships between readers and other agents involved in this chain are shaped in other ways (Murray \& Squires, 2014). Modern book publishing processes are inseparable from the development of information technologies, which has promoted the production and distribution of publications on various digital platforms. The growth of e-books and digital markets determined that many readers have moved to the digital space. The demographic change, shrinking local market and increasing competition determine changes in the modern way of life - books are competing with other media. It is stated that a share of people, especially whose lifestyle is characterized by lower book reading needs and habits, is replacing reading with faster and more user-friendly audiovisual information and that further penetration of technologies will be increasing competition for reader attention. Thus, there is a real threat that if no measures are taken, the book reading intensity will be further decreasing (Lietuvos leidejų asociacija, 2017). The said factors have a major impact on the performance of the publishing sector and require innovative solutions in the areas of products, services, management, and marketing. After performing the theoretical analysis, the following types of innovations in the context of activities of publishing houses were distinguished (Table 1). 
Table 1. The following types of innovations in the context of activities of publishing houses (source: created by authors)

\begin{tabular}{|c|c|}
\hline Innovation type & $\begin{array}{l}\text { In the context of activities of publishing houses, } \\
\text { it should be maintained that innovation is... }\end{array}$ \\
\hline Product innovation & $\begin{array}{l}\text {...new or improved product or service offered by publishing houses, } \\
\text { creative solutions to challenges, which benefit individual readers and } \\
\text { their communities as well as other stakeholders. }\end{array}$ \\
\hline Process innovation & $\begin{array}{l}\text {...the whole of practices of publishing houses in organizing the } \\
\text { production, publication, distribution and sales of publications. }\end{array}$ \\
\hline Marketing innovation & $\begin{array}{l}\text {...the whole of actions and solutions that strengthen the publishing } \\
\text { house's competitive advantage, market position, increase the } \\
\text { organisation's recognisability and attractiveness of its products or } \\
\text { services, stakeholders' interest and involvement in collaboration with } \\
\text { these organizations. }\end{array}$ \\
\hline $\begin{array}{l}\text { Organizational } \\
\text { innovation }\end{array}$ & $\begin{array}{l}\text {...new or substantially improved organizational structures of publishing } \\
\text { houses or implementation of management methods in order to increase } \\
\text { the use of knowledge, the quality of products or services, and the } \\
\text { efficiency of operational processes. }\end{array}$ \\
\hline
\end{tabular}

The study was conducted by choosing 50 member publishing houses registered on the website of the Lithuanian Publishers Association (2017). During the research, the qualitative content analysis of websites of publishing houses and of entries on the social network Facebook during 2021 was conducted. 49 out of 50 publishing houses communicate on the websites they have created and 47 of them use the social network Facebook in their communication. The theoretical analysis resulted in the formulation of the following research categories:

- supply of innovative products and services;

- functions of websites and the social network Facebook in the activities of publishing houses;

- relationships with stakeholder groups and ways of their development;

- involvement of stakeholders and promotion of mutual collaboration;

- forms of promoting stakeholders' knowledge-sharing;

- forms and methods of promoting the manifestation of stakeholders' creativity;

- the role of stakeholders in creating innovation.

Conducting the research, it was decided to choose the aspect of promoting innovation, or practically applicable creativity and knowledge-sharing, through communication in creative organizations, which mainly takes place while developing intellectual-creative products and services. The range of reports was particularly wide; therefore, they were grouped according to the topics and subtopics relevant to the study.

\section{The research results}

The content analysis of corporate websites and the social network Facebook allowed to identify their functions and applicability in the activities of publishing houses, seeking to attract stakeholder groups, forms and ways of promoting their activity, peculiarities of knowledge 
sharing and creativity manifestation as an important constituent of value co-creation processes. As no officially published latest categorization of publishing houses by size and output is available, the study was limited to investigation of the distinguished categories, considering the qualitative aspects of the study.

The supply of innovative products and services in publishing houses is growing, however, rather slowly. It is maintained that innovative products are goods and services that are new or improved versions of previous ones. The study aimed to identify the supply of innovative products, which would increase competitiveness of publishing houses in the market and help them to creatively address the challenges they encounter. The digital era distinguishes itself by a growing need for digital products ordering and use of which would be convenient and clear for customers and would allow them to use their experience in diverse media environment. Publishing houses are expanding the supply of their production: along with publications (books, albums, educational materials, notebooks, etc.), they present games (board games, cards, digital video discs (DVDs)), gifts (souvenirs, cups, home fragrances, etc.), accessories (bracelets, pendants, badges, etc.), music recordings, postcards, and the like. The production assortment is expanding, but in most cases, sales of physical goods are developed. It should be noted that the range of innovative products and services offered by publishing houses is still quite narrow. The prevailing supply is that of traditional paper publications and only a third of publishing houses offer to purchase not only paper books but also ebooks, compact discs, DVDs, and audiobooks. Most of the innovative products and services are presented by publishing houses oriented to the educational community, selling various service packages and integrated innovative products and in addition to e-textbooks, offering the possibility to procure e-tests, puzzles and other additional tasks helping to deepen and apply empirically studied material in the digital space. The growing element in the supply of these publishing houses is namely digital production, which offers interactive learning activities with play elements and the use of animation elements. Such production promotes the involvement of pupil classes in e-learning processes, provides the possibility for teachers to track the pupil's individual progress, and the like. Publishing houses also offer a possibility to purchase e-seminars and e-learning recordings and subscriptions. There is a lack of integration of mobile applications into the supply of digital production, although currently, this market is growing particularly quickly, like the gaming industry. Thus, this plane provides opportunities for cross-sectorial collaboration that could open up new activity perspectives for the publishing sector as well. Innovative services are related to personalization of services, variety of opportunities and flexibility in their provision, diversity of audiovisual production formats, and growing interactivity.

The functions of websites and the social network Facebook in the activities of publishing houses are expanding. It has been stated in the theoretical part that in the digital era, the number of functions of communication channels of organizations is increasing; therefore, the research aimed to identify new ways applied to enhance market position of publishing houses, expand the occupied market share, applied new business practices and methods of enhancing stakeholder relationships. It has been found that innovations can be oriented to processes, relationships with stakeholders and maintaining contacts with them, networking and formation of strategic partnerships. In the digital age, publishing sector innovations are 
primarily developed by moving many activity processes to the virtual space. It should be noted that the website and social networks are becoming an essential tool for the development of the activities of modern organizations, as the digital space is emerging as a place for the formation of new business models. This is driven by the changing market situation: it is relevant not only how customers find the products they need, order and procure them, how they use them, but also what determines their resolve to buy.

The structure of the websites of publishing houses remains rather static and keeps the traditional structure (about us; news; online bookstore; contact us). Publishing houses clearly define their business profile, the target groups they focus on, but there is a lack of a more widely presented business philosophy, values, operating principles, and the like. It has been identified that in the activities of publishing houses, websites perform such functions and activities as the presentation of the organization (activity profile, repertoire of publications, contact information); sales organization and e-commerce; development of marketing support activities (advertising, sales promotion, publicizing of new publications, competitions with the opportunity to win); formation of public relations (links to mentions in the media, presentations of awards to authors and published books, interviews with authors, publication of reviews, invitation to events, and the like); organization of social actions (assistance of publishing houses to educational institutions and the community for the implementation of distance e-learning: organization of free e-lessons and e-seminars); job offers. It can be stated that the sales activities of publishing houses are digitized and websites are largely adapted for the activities of online bookstores and e-sales. As customer service and sales have moved to the digital space, publishing houses are seeking to cope with emerging challenges and looking for ways to ensure a positive customer experience. Digital transformation processes are taking place and operational processes of publishing houses are being streamlined by automating them. Larger publishing houses provide e-catalogues, automated contract forms for orders and for purchase and sale of goods. The most exhaustive provided information is on ordering of publications, payment, and delivery methods.

It has been found that in the activities of publishing houses, the social network Facebook performs similar functions as websites. These are presentation of new products, active sales promotion and support activities, enhancement of the image and reputation of publishing houses, increase of the popularity and awareness of publishing houses by presenting prominent authors, award-winning books, and the most read books. In addition to the account on the social network Facebook, publishing houses usually use other social networks too (YouTube, Instagram); on average, every organization communicates on two social networks. Publishing houses effectively perform marketing activities in the digital space, this way reducing the role of intermediaries who would traditionally organize sales of production of publishing houses. Currently, publishing houses have the possibility to sell wholesale and retail directly, form virtual communities of their readers, identify their needs, attitudes, lifestyles more clearly and find new activity niches, while the developed communication allows them to build long-term relationships with customers and positive user experience. The most significant changes can be observed in the field of marketing of publishing houses. Implementation of this activity encompasses intensive use of websites and social networks of publishing houses, seeking to involve users in communication, encourage them to participate 
in the production, promotion and distribution of new products. It is namely on the social network Facebook that publishing houses develop their relationships with stakeholder groups more intensively, aiming not only to transmit information but also to create the opportunity for participation and involvement of stakeholders in the communication and activities organized by publishing houses. As the activities of publishing houses, carried out on websites and the social network Facebook duplicate, Tables 2 and 3 provide summarized research data.

The effectiveness of communication carried out by publishing houses is demonstrated by the number and activeness of the assembled communities, while the action program is aimed at increasing interest in the activities of publishing houses, formation of their positive reputation and image, and development of continuous relationships with stakeholders.

Table 2. Applicability of the website and the social network Facebook in the marketing activities of Lithuanian publishing houses (source: created by authors)

\begin{tabular}{|c|c|c|}
\hline $\begin{array}{l}\text { Activity } \\
\text { area }\end{array}$ & Aim & $\begin{array}{l}\text { Applicability of the website and social network Facebook in } \\
\text { communication of Lithuanian publishing houses }\end{array}$ \\
\hline \multirow[t]{22}{*}{ Marketing } & \multirow[t]{9}{*}{$\begin{array}{l}\text { Development of } \\
\text { product supply }\end{array}$} & $\begin{array}{l}\text { Traditional publications: books, magazines, albums, educational } \\
\text { materials. }\end{array}$ \\
\hline & & E-books. \\
\hline & & Audiobooks. \\
\hline & & E-seminars and e-learning. \\
\hline & & Interactive services for the educational community: tests, puzzles, etc. \\
\hline & & Cultural education programs. \\
\hline & & Games: board games, cards, digital video discs. \\
\hline & & Accessories: bracelets, badges, pendants, bow ties, etc. \\
\hline & & Gifts: souvenirs, cups, home fragrances, etc. \\
\hline & \multirow{3}{*}{$\begin{array}{l}\text { Development of } \\
\text { sales channels }\end{array}$} & Online ordering platforms and convenient procurement of products. \\
\hline & & $\begin{array}{l}\text { The system of e-catalogues and newsletters, forming a personalized } \\
\text { relationship with users. }\end{array}$ \\
\hline & & Mention of physical habitats, bookstores on e-commerce platforms. \\
\hline & \multirow[t]{2}{*}{ Pricing } & $\begin{array}{l}\text { Flexible pricing policy and promotion of e-commerce (products at a } \\
\text { lower price in e-commerce). }\end{array}$ \\
\hline & & Offers of various product bundles at a lower price. \\
\hline & \multirow{8}{*}{\begin{tabular}{|l|} 
Support \\
activities and \\
sales promotion
\end{tabular}} & Exhaustive product description in online bookstores. \\
\hline & & $\begin{array}{l}\text { Interactive product advertising based on a searcher's browsing } \\
\text { history. }\end{array}$ \\
\hline & & Advertising of other books written by bestselling authors. \\
\hline & & Subscription to news/subscription. \\
\hline & & Publication of excerpts from new books. \\
\hline & & Interviews with authors and virtual meetings. \\
\hline & & Thematic events and new product launch events. \\
\hline & & Presentation of book news and overviews through various channels. \\
\hline
\end{tabular}


End of Table 2

\begin{tabular}{|c|c|c|}
\hline $\begin{array}{l}\text { Activity } \\
\text { area }\end{array}$ & Aim & $\begin{array}{l}\text { Applicability of the website and social network Facebook in } \\
\text { communication of Lithuanian publishing houses }\end{array}$ \\
\hline & & Recommendations of celebrities and opinion leaders on TOP books. \\
\hline & & Webcasts on topics relevant to the target audience. \\
\hline & & $\begin{array}{l}\text { Invitation for readers to share information about new publications } \\
\text { with their followers and friends and the opportunity to win gifts. }\end{array}$ \\
\hline & & Offers of gift ideas for the upcoming holidays. \\
\hline & & Free shipping of the purchase for a certain amount. \\
\hline & & Announcing sale of books at a lower price. \\
\hline & & Column CHEAPER and sale of remainders. \\
\hline & \multirow{3}{*}{$\begin{array}{l}\text { Getting } \\
\text { to know } \\
\text { customers and } \\
\text { identifying } \\
\text { their needs }\end{array}$} & Surveys. \\
\hline & & Reader ratings and feedback. \\
\hline & & Sharing reading experiences by community members. \\
\hline & \multirow{3}{*}{$\begin{array}{l}\text { Promotion } \\
\text { of customer } \\
\text { loyalty }\end{array}$} & Application of loyalty programs. \\
\hline & & Provision of discount codes. \\
\hline & & Personalized offers according to purchase history and interests. \\
\hline
\end{tabular}

Table 3. Applicability of the website and the social network Facebook in the activities of Lithuanian publishing houses in public relations activities (source: created by authors)

\begin{tabular}{|c|c|c|}
\hline $\begin{array}{l}\text { Activity } \\
\text { area }\end{array}$ & Aim & $\begin{array}{l}\text { Applicability of the website and social network Facebook in } \\
\text { communication of Lithuanian publishing houses }\end{array}$ \\
\hline \multirow{13}{*}{$\begin{array}{l}\text { Public } \\
\text { relations }\end{array}$} & \multirow{7}{*}{$\begin{array}{l}\text { Promotion } \\
\text { of interest in } \\
\text { the publishing } \\
\text { house }\end{array}$} & Informative presentation of the publishing house and its activities. \\
\hline & & Interesting facts about the publishing house. \\
\hline & & Awards and achievements of publishing houses. \\
\hline & & Positive feedback and ratings of readers. \\
\hline & & Prizes and awards for guessed puzzles, likes, comments. \\
\hline & & $\begin{array}{l}\text { Events, meetings with creators and educational activities of publishing } \\
\text { houses. }\end{array}$ \\
\hline & & $\begin{array}{l}\text { Inspirational quotes from writers and other famous people on websites } \\
\text { and social networks. }\end{array}$ \\
\hline & \multirow{6}{*}{$\begin{array}{l}\text { Formation } \\
\text { of image and } \\
\text { reputation }\end{array}$} & $\begin{array}{l}\text { Publicising of awards received by books published by publishing houses, } \\
\text { award-winning authors, translators, illustrators, etc. }\end{array}$ \\
\hline & & Presentation of on-going literary projects. \\
\hline & & Links to mentions and publications in the media. \\
\hline & & $\begin{array}{l}\text { Presentation of public benefit activities: donation of published books to } \\
\text { school communities. }\end{array}$ \\
\hline & & $\begin{array}{l}\text { Presentation of innovative solutions in the activities of publishing } \\
\text { houses. }\end{array}$ \\
\hline & & $\begin{array}{l}\text { Development of significant partnerships and visibility of publishing } \\
\text { houses at the events intended for general public, for example, } \\
\text { participation in city celebrations. }\end{array}$ \\
\hline
\end{tabular}


End of Table 3

\begin{tabular}{|c|c|c|}
\hline $\begin{array}{l}\text { Activity } \\
\text { area }\end{array}$ & Aim & $\begin{array}{l}\text { Applicability of the website and social network Facebook in } \\
\text { communication of Lithuanian publishing houses }\end{array}$ \\
\hline & \multirow{8}{*}{$\begin{array}{l}\text { Development } \\
\text { of stakeholder } \\
\text { relationships }\end{array}$} & $\begin{array}{l}\text { Holiday greetings (state, historical, other holidays important to the } \\
\text { target audience) and gifts. }\end{array}$ \\
\hline & & $\begin{array}{l}\text { Encouraging readers to share their reading experiences, feedback, } \\
\text { ratings, and the like. }\end{array}$ \\
\hline & & Interactive experience: puzzles, brain battles, riddles, competitions. \\
\hline & & $\begin{array}{l}\text { Events: meetings with the creators of publications, autograph sharing, } \\
\text { discussions about the creative process. }\end{array}$ \\
\hline & & $\begin{array}{l}\text { Presentation of useful and engaging content: vivacious photos of } \\
\text { readers, interviews with writers. }\end{array}$ \\
\hline & & Gifts for the educational community. \\
\hline & & $\begin{array}{l}\text { Cultural education: reminding the most important dates in history and } \\
\text { excerpts from books about memorable events and people. }\end{array}$ \\
\hline & & $\begin{array}{l}\text { Personalization of relationships: the opportunity to start a direct } \\
\text { conversation with a favourite creator. }\end{array}$ \\
\hline
\end{tabular}

The ways in which relationships with stakeholder groups are built and developed are becoming more diverse and require unprecedented creative smart solutions. In the traditional organization, the purpose of communication was to inform stakeholders about the organization's activities and to form their positive relationship with the organization. Today, it can be stated that positive mentions in the media are no longer a priority, because a much more significant factor in attracting and engaging the audience is regular presentation of interesting and useful content in the channels managed by organizations. Regular communication helps to form the readers' community on social networks, identify topics interesting for the audience, involve them in communication, encourage their feedback, and adapt collaborative activities best suited to the community. Publishing houses are intensifying their activities on their websites notifying their audiences about projects implemented by the publishing house, authors curated by the publishing house, news and on-going changes and providing a possibility to subscribe the publishing house's newsletter. Although the websites provide contact information inviting to contact the publishing house on various issues, a more interactive relationship with the community is developed on the social network Facebook. Posts are posted regularly, their language is less formal than on websites, members of the community are addressed directly using warm addresses (friends, fellows, dear, and the like), rhetorical questions and texts are supplemented with photos, videos, graphics interchange formats, etc. Although book news, planned events and meetings are also presented in this space, the recordings present real-time events and relevant issues, offer creative and cognitive activities, and attempt to encourage manifestation of community feedback and engagement. Feedback is promoted by discussing topics that are relevant for the community, the invitation to share one's opinion on publications and the reader's experience, to evaluate, vote, answer mini-survey questions, and the like. To increase involvement, publishing houses employ such measures as seminars and meetings on topics relevant to the audience, discussions with creators, organize competitions, creative workshops, etc. When discussing the role of 
communication in the modern organization and analyzing value co-creation as a process in which all stakeholder parties act as equal partners having equal power, it is important to note that all constituents are significant: informing stakeholders, feedback from stakeholders and dialogue with them, stakeholder involvement into activity processes and their participation in them. However, value co-creation processes require the most intensive involvement of all stakeholders and equal collaboration between them, which can be developed in various ways and formats.

Based on the information on the websites, stakeholder involvement and collaboration take place at various levels and acquire diverse forms and ways of interaction. Partners named on the websites of publishing houses include various organizations and institutions: editorial boards of magazines, art galleries, support and charity foundations, children and youth centers, kindergartens and schools, libraries, museums, cinemas, magazine and book distribution companies in Lithuania and abroad, publishing houses and distributors of other countries, organizers of major European book fairs, businesses, etc. The analysis of the research data reveals that the most active development of collaboration takes place at the inter-institutional level, producing more clearly expressed outcomes of co-creation activities. The concentrated forces of collaborating institutions and organizations allow to use the resources available in each of the parties: available physical spaces, professionals distinguishing themselves by particular competencies, managed communication channels while implementing and publicizing various project activities. The very result of collaboration is directed to users and the creation of valuable experience for them: publishing of new publications, organization of joint events, new meeting formats or creative workshops (Table 4).

Table 4. Forms and methods of involving stakeholders of Lithuanian publishing houses in collaboration (source: created by authors)

\begin{tabular}{|c|c|}
\hline Levels of interaction & $\begin{array}{l}\text { Forms and methods of involving stakeholders of } \\
\text { Lithuanian publishing houses in collaboration }\end{array}$ \\
\hline \multirow{5}{*}{$\begin{array}{l}\text { Informing stakeholders } \\
\text { about on-going } \\
\text { activities and promotion } \\
\text { of participation }\end{array}$} & Announcement of information about new products, services, events. \\
\hline & Publication of articles and reviews about publications. \\
\hline & Creators' video stories about creative processes. \\
\hline & $\begin{array}{l}\text { Sharing media publications and reportages about the publishing house's } \\
\text { achievements and ongoing projects. }\end{array}$ \\
\hline & Book reviews. \\
\hline \multirow{6}{*}{$\begin{array}{l}\text { Stakeholder feedback, } \\
\text { consultations and } \\
\text { discussions }\end{array}$} & Readers' proposals and requests regarding new publications. \\
\hline & $\begin{array}{l}\text { Invitation to meetings with creators and encouragement to ask questions } \\
\text { and participate in discussions. }\end{array}$ \\
\hline & Invitation of the community to share comments on published books. \\
\hline & $\begin{array}{l}\text { Invitation of the community to vote on a topic proposed by the } \\
\text { publishing house. }\end{array}$ \\
\hline & Invitation to listen to excerpts from the books read live by the authors. \\
\hline & Invitation of all stakeholders to share new ideas. \\
\hline
\end{tabular}


End of Table 4

\begin{tabular}{|c|c|}
\hline Levels of interaction & $\begin{array}{l}\text { Forms and methods of involving stakeholders of } \\
\text { Lithuanian publishing houses in collaboration }\end{array}$ \\
\hline \multirow{5}{*}{$\begin{array}{l}\text { Stakeholder } \\
\text { participation and } \\
\text { involvement in } \\
\text { operational processes of } \\
\text { publishing houses }\end{array}$} & $\begin{array}{l}\text { Election of a cover for a new book from several proposed versions } \\
\text { (Dominicus Lithuanus). }\end{array}$ \\
\hline & Publication of booklets with drawings produced by young readers (Flint). \\
\hline & Organization of creative workshops for readers. \\
\hline & $\begin{array}{l}\text { Competition for young book reviewers or those who want to become } \\
\text { ones. }\end{array}$ \\
\hline & $\begin{array}{l}\text { Request for community members to allocate } 1.2 \text { percent of the already } \\
\text { paid personal income tax to the publishing house. }\end{array}$ \\
\hline \multirow[t]{9}{*}{ Value co-creation } & $\begin{array}{l}\text { Action "Summer with a Book", organized by joint efforts of publishing } \\
\text { houses and their partners, and gifts for those who overcome challenges. }\end{array}$ \\
\hline & $\begin{array}{l}\text { Collaboration projects of publishing houses with libraries and } \\
\text { organization of interactive summer reading rooms to increase the } \\
\text { readability of young audiences. }\end{array}$ \\
\hline & $\begin{array}{l}\text { Collaboration between publishing houses and conversion of traditional } \\
\text { book formats into digital: publication of paper books published by } \\
\text { Eugrimas in audioformat (Audioteka, 2014-2021). }\end{array}$ \\
\hline & $\begin{array}{l}\text { Pupils' involvement in research activities: publication of a series of } \\
\text { articles about Africa, prepared by them. }\end{array}$ \\
\hline & $\begin{array}{l}\text { Collaboration of publishing houses with film representatives: issued } \\
\text { publications and curation of a respective film program on the same topic. }\end{array}$ \\
\hline & Publishing of the content created by community members. \\
\hline & $\begin{array}{l}\text { Invitation of the community members to share their own and their } \\
\text { mothers' recipes, part of which will be included in the new reader recipe } \\
\text { book issued by the publishing house. }\end{array}$ \\
\hline & $\begin{array}{l}\text { Museums and galleries provide spaces for events organized by publishing } \\
\text { houses and for presentation of new books. }\end{array}$ \\
\hline & Photo competitions. \\
\hline
\end{tabular}

Still, the value co-creation process requires the involvement of all parties, and especially the participation of the readers' community in these processes. Involvement of the readers' community in various activities, encouragement to share insights, ideas, proposals, experiences and knowledge, participate in competitions enable publishing houses and their partners to find new product ideas, involve them in the processes of product development and presentation to the market. In the rapidly changing environment, creative behavior and thinking remain among the most important competencies and conditions for the development of innovative activities, while social networks come to prominence as stakeholder collaboration platforms in which representatives of publishing houses have to perform an important role in promoting creative productivity of stakeholders. Many innovations of publishing houses are grounded on value co-creation that is significantly determined by the contribution of the readers' community, partnerships with various institutions, partnership networks and collaboration in them. 


\section{Discussion}

In the context of the need for continuous innovation, the ability of organizations to creatively use their possessed knowledge and competencies that form the basis for innovation development becomes particularly prominent. The competence of innovativeness and creativity is related to the abilities to generate new ideas and apply new work methods in organizational activities. Because innovativeness is related to the search for new ways of problem solving and positive response to innovation, this encourages to revert promotion of creativity among the organization's stakeholder groups, networking and partnership development as well as to collective collaboration, which is increasingly maintained as the foundation of the entire organization's success. Creative problem solving by enabling diverse experience, attitudes, knowledge and creativity of stakeholders provides an opportunity to find non-standard and innovative ways of tackling problems and the niche in the market. Creativity can result in a radically new idea, service or product that are implemented by introducing innovation. New knowledge is created by people by way of using their creative, intellectual potential, the already existing knowledge, and it is collective work that plays an important role in this knowledge building process. The relation of knowledge, creativity and communication in the modern society proves that soft capital displaces traditional hard, or financial, capital as the basis of economy. Competitive advantage and innovation development require that organizations should focus on creatively strategic knowledge building, its effective transfer and promotion during communication processes, involving stakeholders.

In the age of digitization, organizations have to be able to adapt to the logic of cyberspace operations, while websites and social networks no longer serve solely as the organization's business card - they are becoming vitally important for the development of organizational activities. The study has found that publishing houses issuing publications on respective topics (business, investment, education, religion, psychology) develop their activities on online platforms, not limiting themselves only to publishing activities. Such online platforms turn into a space for collaboration between professionals in the respective field and a new niche for publishing houses. They serve for the procurement of publications, e-seminars, trainings, consultations and other services. This way, the formation of new activity models and the entrenchment of publishing houses in the training sector can be observed. This allows to speak about value co-creation processes through mobilization of various stakeholders and the formation of a common vision of operations, and these factors enable to transcend the boundaries of one organization, implement larger-scale projects, and achieve more weighty results.

Communication of publishing houses, carried out through digital channels, helps to build connections with stakeholders, involve them in the organization's activity processes as full partners with equal decision-making power. Innovativeness pertains to the search for new ways of problem-solving and positive reaction to novelties, which encourages to revert to experience, knowledge, creative powers of stakeholders of creative organizations and to enable them, because they become the basis of the competitive advantage of the whole organization. The study has found that product innovation in publishing houses is developed in several directions: through the supply of various formats (e-books, audiobooks, etc.), 
the multidimensionality of book illustrations, the supply of integrated service packages (supplementation of publications with interactive activities in cyberspace: tests, trainings, and the like), development of online activities (virtual meetings, discussions, educational sessions), etc. The study has also revealed process innovations introduced by publishing houses: automation of ordering and shipment services, submission of e-forms of purchase and sale agreements to educational communities, development of online services, etc. It is evident that publishing houses increasingly actively develop their activities directly, becoming less and less dependent on sales intermediaries (for example, bookstores) and building direct relationships with readers. The range of implemented marketing innovations is quite wide: presentations of publishing houses and their production in various formats, selection of unusual mobile locations to sell products (for example, mobile bookstores in the places of summer holidays), various sales that promote selling, etc. Publishing houses are increasingly promoting stakeholder feedback and discussions enabling a better understanding of societal trends, the reading peculiarities of readers, and the determinants of their ratings and choices. Social networks enable personalization of the relationships between creators of publications and readers, and the two-way communication helps to form the sense of community among followers, promotes their involvement in creative processes, allows the whole community that takes part in creative decision-making processes, discussions and collaboration to become creators. Such two-way communication is valuable when it both helps to form connections between the publishing house and its followers on social networks and promotes discussions between them and the sense of community. In innovation activities, experimentation and collaboration are important, but these processes can only take place if relationships are based on trust. The announcement of various creative competitions helps to involve community members in content creation and sharing; i.e., to become co-authors of the content published on communication channels managed by publishing houses, and encourages them to become co-authors of publications and contribute their ideas to the development of new products. Communication with stakeholders and their feedback helps publishing houses to perceive value aspects significant to them, realize their needs and problems the solution of which creates new experiences. Thus, it can be stated that communication activities are a multi-level purposeful transition from stakeholders' informing to discussions and collaboration with them. However, the most significant stage for all stakeholders is value co-creation processes enabling the interaction between stakeholder groups and ending with the implementation of innovative solutions in the activities of publishing houses.

\section{Conclusions}

Cultural and creative industries of the 20th-21st centuries are characterized by a transition to a conceptually new field, transforming contemporary culture, media and the economy into a new social reality. In this context, relevance of the interaction between communication, knowledge and creativity for the development and dissemination of continuous innovation is increasing. All of it promotes to focus on creative development and sharing of knowledge in communication processes enabling innovation creation namely due to the creative 
application of knowledge. Knowledge management requires abilities to apply it creatively so that existing processes and products are improved or new ones that could be transformed into innovative processes, products or services are created.

The modern organization distinguishes itself by the growing role of collective creativity, while the whole team is becoming a source of innovation. A particularly significant role in promoting the modern organization's collective creativity is played by communication. The communication strategy must help to create sustainable relationships between the organization's stakeholders and promote an innovation-friendly environment: co-creativity, learning, sharing useful experiences, effective solution of arising problems, and the like.

In the context of activities of publishing houses, innovation pertains to the improvement of publishing processes, the change in the form or genre of the book, new functions including interactivity, distribution methods, etc. The specificity of creative organizations also determines certain factors promoting creative innovation: flexibility, mobility, the ability to learn and efficiently share experiences, tolerance to innovation, and courage to take up non-traditional activities or to implement ideas at the cross-sectorial level. The connection between knowledge and creativity is one of the essential conditions for promoting innovation in the publishing sector, but only a third of Lithuanian publishing houses undertake to create digital production.

Publishing houses actively employ their existing websites and accounts on the social network Facebook for presentation, selling, and publicizing of their production. Summarizing the value co-creation processes in publishing houses, it can be stated that stakeholder collaboration as a co-value creation process takes place in several directions. The concerted efforts and resources of partners of organizations allow to create and implement larger-scale projects, using existing contacts and competencies, and to reach a wider audience by employing available communication channels. Involvement of the community of social network Facebook in communication provides an opportunity for publishing houses to better perceive value aspects that are significant for other stakeholders, realize unimplemented needs, receive proposals regarding new products, involve community members in the product development process, enabling knowledge, experience and creative powers of all stakeholders.

\section{References}

Ackermann, M. (2013). The communication of innovation - an empirical analysis of the advancement of innovation. In Discussion Papers on Strategy and Innovation 13-02. https://www.econstor.eu/ obitstream/10419/77064/1/751413305.pdf

Albronda, B., Langen, de F., \& Huizing, B. (2011). The influence of communication on the process of innovation adoption. Innovative Management Journal, 4(1), 22-31.

Atanassova, I., \& Clark, L. (2015). Social media practices in SME marketing activities: A theoretical framework and research agenda. Journal of Customer Behavior, 14(2), 163-183. https://doi.org/10.1362/147539215X14373846805824

Atkočiūnienė, Z., Siudikienè, D., \& Girnienè, I. (2019). Inovatyvios lyderystès vaidmuo žinių valdymo ir inovacijų kūrimo procesuose šiuolaikinèje organizacijoje. Informacijos mokslai, 86, 68-97.

https://doi.org/10.15388/Im.2019.86.27

Audioteka. (2014-2021). Audioteka. https://audioteka.com/lt/?_rd 
Ayuso, S., Rodríguez, M. Á., \& Ricart, J. E. (2006). Using stakeholder dialogue as a source for new ideas: A dynamic capability underlying sustainable innovation. Corporate Governance, 6(4), 475-490. https://doi.org/10.1108/14720700610689586

Baumgartner, R. J. (2014). Managing corporate sustainability and CSR: A conceptual framework combining values, strategies and instruments contributing to sustainable development. Corporate Social Responsibility and Environment Management, 21(5), 258-271. https://doi.org/10.1002/csr.1336

Beckett, R. C., \& Hyland, P. (2009, 4-8 September). Effective communication in innovation processes. In 10th International Continuous Innovation Network (CINet) Conference "Enhancing the Innovation Environment”. Brisbane, Australia. https://eprints.qut.edu.au/27155/1/CINet_09_-_Beckett.pdf

Benner, M. J., \& Tushman, M. L. (2003). Exploitation, exploration, and process management: The productivity dilemma revisited. The Academy of Management Review, 28(2), 238-256. https://doi.org/10.5465/amr.2003.9416096

Bernal Jurado, E., Mozas Moral, A., Medina Viruel, M. J., \& Fernández Uclés, D. (2018). Evaluation of corporate websites and their influence on the performance of olive oil companies. Sustainability, 10(4). https://doi.org/10.3390/su10041274

Bosch, van den A. L. M., Elving, W. J. L., \& Jong, de M. D. T. (2006). The impact of organisational characteristics on corporate visual identity. European Journal of Marketing, 40(7-8), 870-885. https://doi.org/10.1108/03090560610670034

Boyd, D. E., \& Koles, B. (2019). Virtual reality and its impact on B2B marketing: A value-in-use perspective. Journal of Business Research, 100, 590-598. https://doi.org/10.1016/j.jbusres.2018.06.007

Brem, A., Bilgram, V., \& Marchuk, A. (2019). How crowdfunding platforms change the nature of user innovation - from problem solving to entrepreneurship. Technological Forecasting and Social Change, 144, 348-360. https://doi.org/10.1016/j.techfore.2017.11.020

Capriotti, P., Zeler, I., \& Camilleri, M. A. (2021). Corporate communication through social networks: The identification of the key dimensions for dialogic communication. In M. A. Camilleri (Ed.), Strategic corporate communication in the digital age (pp. 33-52). Emerald Publishing. https://doi.org/10.1108/978-1-80071-264-520211003

Carlson, C. R., \& Wilmot, W. W. (2006). Innovation: The five disciplines for creating what customers want. Crown Business.

Chutivongse, N., \& Gerdsri, N. (2020). Creating an innovative organization: Analytical approach to develop a strategic roadmap guiding organizational development. Journal of Modelling in Management, 15(1), 50-88. https://doi.org/10.1108/JM2-05-2018-0067

Cina, A., \& Cummings, S. (2018). Open innovation communication: improving strategy implementation in the public sector. Policy Quarterly, 14(1), 74-80. https://doi.org/10.26686/pq.v14i1.4753

Cortado, F.-J., \& Chalmeta, R. (2016). Use of social networks as a CSR communication tool. Cogent Business and Management, 3(1). https://doi.org/10.1080/23311975.2016.1187783

Cronquist, B., Johansson, L.-O., \& Kjellin, H. (2006). Communication enabling the implementation of innovation. In O. Wedege Bertelsen (Ed.), IRIS 29 Paradigms Politics Paradoxes: Proceedings of 29th Information Systems Research Seminar in Scandinavia (pp. 1-15). 2006 CD ROM. Helsingør, Denmark. AIS.

Černevičiūtè, J., \& Strazdas, R. (2014). Kūrybingumo sampratų raida: nuo genijaus ị kūrybines sistemas. Santalka: filosofija, komunikacija, 22(2), 113-125.

Černevičiūtè, J., Strazdas, R., Jančoras, Ž., Kregždaitė, R., \& Morkevičius, V. (2015). Kūrybiniu industriju plètojimo kompleksiniai veiksniai: kolektyvinio kūrybingumo ugdymas. Technika.

Drucker, P. F. (2006). Innovation and entrepreneurship. HarperBusiness.

Egerová, D., \& Eger, L. (2017, 3-4 May). Recruitment through the use of corporate websites: A comparative study. In K. S. Soliman (Ed.), Proceedings of the 29th International Business Information Man- 
agement Association (IBIMA) Conference. Education Excellence and Innovation Management through Vision 2020: From Regional Development Sustainability to Global Economic Growth (pp. 1137-1149). Vienna, Austria. International Business Information Management Association.

Fan, X., \& Luo, Y. (2020). Value co-creation: A literature review. Open Journal of Social Sciences, 8(2), 89-98. https://doi.org/10.4236/jss.2020.82008

García García, M., Carrillo-Durán, V., \& Tato Jimenez, J. L. (2017). Online corporate communications: Website usability and content. Journal of Communication Management, 21(2), 140-154. https://doi.org/10.1108/JCOM-08-2016-0069

Gill, R., Levine, N., \& Pitt, D. C. (1999). Leadership and organizations for the new millennium. Journal of Leadership and Organizational Studies, 5(4), 46-59. https://doi.org/10.1177/107179199900500405

Girnienè, I. (2014). Žinių valdymo įtaka nuolatiniam inovacijų kūrimui: atvejo analizè. Informacijos mokslai, 68, 44-62. https://doi.org/10.15388/Im.2014..3921

Government of the Republic of Lithuania. (2013). The Lithuanian Innovation Development Programme 2014-2020. https://mita.lrv.lt/uploads/mita/documents/files/_en/national-programmes/innovationin-lithuania/lithuanian_innovation_programme.pdf

Granados, C., Pareja, M., \& Bernardo, M. (2017, 10-12 September). Innovation process in creative industries: Insights from the mobile games sector. In 18th International Continuous Innovation Network (CINet) Conference "Digitalization and Innovation: Designing the Organization of the Future". Potsdam, Germany. https://doi.org/10.1080/17510694.2017.1393192

Gustafsson, A., Kristensson, P., \& Witell, L. (2012). Customer co-creation in service innovation: A Matter of communication? Journal of Service Management, 23(3), 311-327. https://doi.org/10.1108/09564231211248426

Gustavsen, P. A., \& Tilley, E. (2003). Public relations communication through corporate websites: Towards an understanding of the role of interactivity. Prism, 1(1). http://praxis.massey.ac.nz/fileadmin/Praxis/Files/Journal_Files/issue1/refereed_articles_paper5.pdf

Hargie, C., \& Tourish, D. (1996). Corporate communication in the management of innovation and change. Corporate Communications: An International Journal, 1(2), 3-11.

https://doi.org/10.1108/eb046524

Hein, A., Weking, J., Schreieck, M., Wiesche, M., Böhm, M., \& Krcmar, H. (2019). Value co-creation practices in Business-To-Business platform ecosystems. Electronic Markets, 29, 503-518. https://doi.org/10.1007/s12525-019-00337-y

Helkkula, A., Kelleher, C., \& Pihlström, M. (2012). Characterizing value as an experience: Implications for service researchers and managers. Journal of Service Research, 15(1), 59-75. https://doi.org/10.1177/1094670511426897

Hoffmann, Ch. P., \& Lutz, Ch. (2015). The impact of online media on stakeholder engagement and the governance of corporations. Journal of Public Affairs, 15(2), 163-174. https://doi.org/10.1002/pa.1535

Horth, D., \& Buchner, D. (2014). Innovation leadership: How to use innovation to lead effectively, work collaboratively, and drive results. https://encc.eu/sites/default/files/2016-11/InnovationLeadership\%20.pdf

Huck, S. (2006). New perspectives on innovation communication: Findings from Germany's survey INNOVATE 2006. Innovation Journalism, 3(4). https://www.innovationjournalism.org/archive/injo3-4/Huck.pdf

Hwang, J.-S., McMillan, S. J., \& Lee, G. (2003). Corporate web sites as advertising: An analysis of function, audience, and message strategy. Journal of Interactive Advertising, 3(2), 10-23. https://doi.org/10.1080/15252019.2003.10722070

Jansen, J. J. P., Bosch, van den F. A. J., \& Volberda, H. W. (2006). Exploratory innovation, exploitative innovation, and performance: Effects of organizational antecedents and environmental moderators. Management Science, 52(11), 1661-1674. https://doi.org/10.1287/mnsc.1060.0576 
Jones, III G. E. J. (2017). Knowledge sharing and technological innovation: The effectiveness of trust, training, and good communication. Cogent Business and Management, 4(1). https://doi.org/10.1080/23311975.2017.1387958

Jun, H., \& Kim, M. (2021). From stakeholder communication to engagement for the Sustainable Development Goals (SDGs): A case study of LG Electronics, Sustainability, 13. https://doi.org/10.3390/su13158624

Kačerauskas, T. (2017). Kürybos visuomene. Technika. https://doi.org/10.20334/2017-014-M

Kenney, M. (Ed.). (2000). Stanford Business Books. Understanding Silicon Valley: The anatomy of an entrepreneurial region. Stanford University Press.

Kim, J., \& Choi, H. (2019). Value co-creation through social media: A case study of a start-up company. Journal of Business Economics and Management, 20(1), 1-19. https://doi.org/10.3846/jbem.2019.6262

Kim, Ch., Galliers, R. D., Shin, N., Ryoo, J.-H., \& Kim, J. (2012). Factors influencing internet shopping value and customer repurchase intention. Electronic Commerce Research and Applications, 11(4), 374-387. https://doi.org/10.1016/j.elerap.2012.04.002

Kim, K. K., Shin, H. K., \& Kim, B. (2011). The role of psychological traits and social factors in using new mobile communication services. Electronic Commerce Research and Applications, 10(4), 408-417. https://doi.org/10.1016/j.elerap.2010.11.004

Lazzeretti, L. (Ed.). (2013). Regions and cities. Creative industries and innovation in Europe: Concepts, measures and comparative case studies. R. Martin, G. Grabher, M. Feldman, \& G. Bristow (Series Eds.). Routledge.

Lewis, L. K., Schmisseur, A. M., Stephens, K. K., \& Weir, K. E. (2006). Advice on communicating during organizational change: The content of popular press books. International Journal of Business Communication, 43(2), 113-137. https://doi.org/10.1177/0021943605285355

Lietuvos leidejų asociacija. (2017). Knygų leidybos sektoriaus vystymasis Lietuvoje: apžvalga. http://www. kulturostyrimai.lt/wp-content/uploads/2017/08/Knygu_leidybos_sektoriaus_vystymasis_Lietuvoje_apzvalga.pdf

Linke, A., \& Zerfass, A. (2011). Internal communication and innovation culture: Developing a change framework. Journal of Communication Management, 15(4), 332-348. https://doi.org/10.1108/13632541111183361

López-Rubio, P., Roig-Tierno, N., \& Mas-Tur, A. (2020). Regional innovation system research trends: Toward knowledge management and entrepreneurial ecosystems. International Journal of Quality Innovation, 6(4). https://doi.org/10.1186/s40887-020-00038-x

Luoma-aho, V., \& Halonen, S. (2010). Intangibles and innovation: The role of communication in the innovation ecosystem. Innovation Journalism, 7(2). http://journal.innovationjournalism.org/2010/11/ intangibles-innovation-role-of.html

Maceika, A., \& Jančiauskas, B. (2012). Inovatyvios žinios: jų kilmė, išskyrimas ir naudojimas gamybinèje veikloje. Verslas: teorija ir praktika, 13(3), 228-233. https://doi.org/10.3846/btp.2012.24

Makselis, R. (2014). Kūrybinès industrijos ir tarpsektorinè inovacijų sąveika. Acta Academiae Artium Vilnensis, 72, 7-30.

Martinaityte, E., \& Kregždaitė, R. (2013). Kūrybinių industrijų ịtaka ekonomikos plètrai. Socialinių mokslu studijos, 5(4), 1094-1108. https://doi.org/10.13165/SMS-13-5-4-09

Martinaityte, E., \& Kregždaite, R. (2015). The factors of creative industries development in nowadays stage. Economics and Sociology, 8(1), 56-71. https://doi.org/10.14254/2071-789X.2015/8-1/5

Martini, A., Massa, S., \& Testa, S. (2014). Customer co-creation projects and social media: The case of Barilla of Italy. Business Horizons, 57(3), 425-434. https://doi.org/10.1016/j.bushor.2014.02.003

Mast, C., Huck, S., \& Zerfass, A. (2005). Innovation communication: Outline of the concept and empirical findings from Germany. Innovation Journalism, 2(7). https://www.innovationjournalism.org/ archive/injo-2-7.pdf 
Mastio, E., Chew, E., \& Dovey, K. A. (2020). The learning organization as a context for value cocreation. The Learning Organization, 27(4), 291-303. https://doi.org/10.1108/TLO-12-2018-0219

Miller, P. (2012). Leadership communication: The three levels. Today's Manager (February-March), 19-21.

Mumford, M. D., Zaccaro, S. J., Harding, F. D., Jacobs, T. O., \& Fleishman, E. A. (2000). Leadership skills for a changing world: Solving complex social problems. The Leadership Quarterly, 11(1), 11-35. https://doi.org/10.1016/S1048-9843(99)00041-7

Murray, P. R., \& Squires, C. (2014). Skaitmeninès leidybos komunikacinė grandinè. Knygotyra, 62, 18-46. https://doi.org/10.15388/kn.v62i0.3611

Obednikovska, S., Sotiroski, K., \& Gjorgjioska, E. (2019). Web site - basic internet marketing strategy tool of digital companies. Annals of the "Constantin Brâncuşi" University of Târgu Jiu: Economy Series, 3, 82-91.

Ode, E., \& Ayavoo, R. (2020). The mediating role of knowledge application in the relationship between knowledge management practices and firm innovation. Journal of Innovation and Knowledge, 5(3), 210-218. https://doi.org/10.1016/j.jik.2019.08.002

Oliveira, de D. Th., \& Nogueira Cortimiglia, M. (2017). Value co-creation in web-based multisided platforms: A conceptual framework and implications for business model design. Business Horizons, 60(6), 747-758. https://doi.org/10.1016/j.bushor.2017.07.002

O'Riordan, L., \& Fairbrass, J. (2008). Corporate Social Responsibility (CSR): Models and theories in stakeholder dialogue. Journal of Business Ethics, 83, 745-758. https://doi.org/10.1007/s10551-008-9662-y

Parveen, F., Jaafar, N. I., \& Sulaiman, A. (2015, 5-9 July). Role of social media on information accessibility. In Pacific Asia Conference on Information Systems (PACIS) 2015 Proceedings 237. Singapore, Singapore. https://aisel.aisnet.org/pacis2015/237/

Pfitzer, M. W., Bockstette, V., \& Stamp, M. (2013). Innovating for shared value. Harvard Business Review. https://hbr.org/2013/09/innovating-for-shared-value

Ramírez, M.-S., \& García-Peñalvo, F.-J. (2018). Co-creation and open innovation: Systematic literature review. Comunicar, 54(26), 9-18. https://doi.org/10.3916/C54-2018-01

Ranjan, K. R., \& Read, S. (2016). Value co-creation: Concept and measurement. Journal of the Academy of Marketing Science, 44, 290-315. https://doi.org/10.1007/s11747-014-0397-2

Raudeliūnienè, J. (2012). Žinių vadyba. Technika. https://doi.org/10.3846/1287-S

Raudeliūnienė, J., \& Račinskaja, I. (2014). Žinių igijimo proceso vertinimas Lietuvos draudimo sektoriuje. Verslas: teorija ir praktika, 15(1), 149-159. https://doi.org/10.3846/btp.2014.15

Razmerita, L., \& Kirchner, K. (2011). How Wikis can be used to manage knowledge in SMEs: A case study. Business Information Review, 28(3), 175-178. https://doi.org/10.1177/0266382111420354

Rocha, Th. V., Stedefeldt Jansen, C. L., Lofti, E., \& Ribeiro Fraga, R. (2013). An exploratory study on the use of social networks in building customer relationships. Review of Business Management, 15(47), 262-282. https://doi.org/10.7819/rbgn.v15i47.953

Rogers, E. M. (1983). Diffusion of innovations. The Free Press.

Ruževičius, J. (2007). Kokybès vadybos metodai ir modeliai. Vilniaus universiteto leidykla.

Ryan, J. C., \& Daly, T. M. (2019). Barriers to innovation and knowledge generation: The challenges of conducting business and social research in an emerging country context. Journal of Innovation and Knowledge, 4(1), 47-54. https://doi.org/10.1016/j.jik.2017.10.004

Sapiegienė, L., Juknevičienė, V., \& Stoškus, S. (2009). Inovacijų diegimo procesas: Šiaulių miesto gamybos įmonių atvejų analizè. Ekonomika ir vadyba: aktualijos ir perspektyvos, 2(15), 237-249.

Schork, S., Heblich, B., \& Terzidis, O. (2016). Effective innovation leadership. https://www.academia. edu/43781840/Effective_Innovation_Leadership 
Schumann, D. W., Hathcote, J. M., \& West, S. (1991). Corporate advertising in America: A review of published studies on use, measurement, and effectiveness. Journal of Advertising, 20(3), 35-56. https://doi.org/10.1080/00913367.1991.10673346

Strazdas, R. (2011). Produkto inovacijų kūrimas kūrybinių industrijų ịmonèse. Santalka: filosofija, komunikacija, 19(2), 17-28. https://doi.org/10.3846/coactivity.2011.11

Strazdas, R., Bareika, R., \& Toločka, E. (2010). Kūrybiškumo skatinimo plètojant inovacijas metodiniai aspektai. Mechanika, medžiagu inžinerija, pramonés inžinerija ir vadyba, 2(4), 77-82.

Strazdas, R., Jakubavičius, A., \& Gečas, K. (2003). Inovacijos: finansavimas, rizikos kapitalas. Lietuvos inovacijų centras.

Sydänmaanlakka, P. (2008, 28-30 May). Intelligent leadership and creativity: Supporting creativity through intelligent leadership. In The 2nd Creativity and Innovation Management Community Meeting: Integrating Inquiry and Action. Buffalo, New York, United States. https://www.pertec.fi/userfile/ files/files/Artikkeli\%20Intelligent\%20leadership\%20and\%20creativity\%20-\%20Intelligent\%20leadership\%20and\%20creativity.pdf

Trüby, J., Rammer, Ch., \& Müller, K. (2008). The role of creative industries in industrial innovation. In ZEW Discussion Papers 08-109. https://www.econstor.eu/bitstream/10419/27592/1/dp08109.pdf

Tsutsumi, D. P., Fenerich, A. T., \& Silva, Th. H. (2019). Towards business partnership recommendation using user opinion on Facebook. Journal of Internet Services and Applications, 10(11). https://doi.org/10.1186/s13174-019-0110-2

Ulbinaitè, A., \& Gribovskis, J. (2020). Žinių valdymo procesų ir verslo procesų integracijos sąveikos vertinimo modelis. Informacijos mokslai, 88, 142-166. https://doi.org/10.15388/Im.2020.88.36

Urgal, B., Quintás, M. A., \& Arévalo-Tomé, R. (2013). knowledge resources and innovation performance: The mediation of innovation capability moderated by management commitment. Technology Analysis and Strategic Management, 25(5), 543-565. https://doi.org/10.1080/09537325.2013.785514

Vlok, A. (2012). A leadership competency profile for innovation leaders in a science-based research and innovation organization in South Africa. Procedia - Social and Behavioral Sciences, 41, 209-226. https://doi.org/10.1016/j.sbspro.2012.04.025

Winkler, L., \& Zerfass, A. (2016). Strategy and organizational culture - conceptualizing the interplay of key concepts in communication. Globe: A Journal of Language, Culture and Communication, 3, $108-120$.

Zerfass, A. (2005). Innovation readiness: A framework for enhancing corporations and regions by innovation communication. Innovation Journalism, 2(8). https://www.researchgate.net/publication/239595285_Innovation_Readiness_A_Framework_for_Enhancing_Corporations_and_Regions_by_Innovation_Communication

Zerfass, A., \& Huck, S. (2007). Innovation, communication, and leadership: New developments in strategic communication. International Journal of Strategic Communication, 1(2), 107-122. https://doi.org/10.1080/15531180701298908

Zhang, H., Lu, Y., Gupta, S., \& Zhao, L. (2014). What motivates customers to participate in social commerce? The impact of technological environments and virtual customer experiences. Information and Management, 51(8), 1017-1030. https://doi.org/10.1016/j.im.2014.07.005 